\title{
The leishmanicidal effect of Lucilia sericata larval saliva and hemolymph on in vitro Leishmania tropica
}

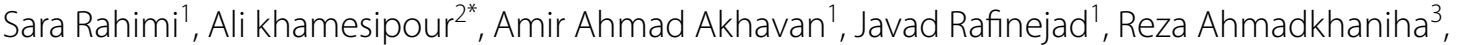 \\ Mahmood Bakhtiyari ${ }^{4}$, Arshad Veysi ${ }^{5}$ and Kamran Akbarzadeh ${ }^{{ }^{*}}$
}

\begin{abstract}
Background: Leishmaniasis is a major parasitic disease worldwide, except in Australia and Antarctica, and it poses a significant public health problem. Due to the absence of safe and effective vaccines and drugs, researchers have begun an extensive search for new drugs. The aim of the current study was to investigate the in vitro leishmanicidal activity of larval saliva and hemolymph of Lucilia sericata on Leishmania tropica.
\end{abstract}

Methods: The effects of different concentrations of larval products on promastigotes and intracellular amastigotes of L. tropica were investigated using the mouse cell line J774A.1 and peritoneal macrophages as host cells. The 3-(4.5-dimethylthiazol-2-yl)-2,5-diphenyltetrazolium bromide (MTT) assay and direct observation and counting method were used to assess the inhibitory effects and cell cytotoxicity of the larval products. The effects of larval products on the amastigote form of $L$. tropica were quantitatively estimated by calculating the rate of macrophage infection, number of amastigotes per infected macrophage cell, parasite load and survival index.

Results: The $50 \%$ cytotoxicity concentration $\left(\mathrm{CC}_{50}\right)$ value of both larval saliva and hemolymph was $750 \mu \mathrm{g} / \mathrm{ml}$, and the $50 \%$ inhibitory concentration $\left(\mathrm{IC}_{50}\right)$ values were $134 \mu \mathrm{g} / \mathrm{ml}$ and $60 \mu \mathrm{g} / \mathrm{ml}$ for larval saliva and larval hemolymph, respectively. The $\mathrm{IC}_{50}$ for Glucantime, used a positive control, was $(11.65 \mu \mathrm{g} / \mathrm{ml})$. Statistically significant differences in viability percentages of promastigotes were observed for different doses of both larval saliva and hemolymph when compared with the negative control ( $p \leq 0.0001)$. Microscopic evaluation of the amastigote forms revealed that

\footnotetext{
*Correspondence: ali.khamesipour@gmail.com; kakbarzadeh@tums.ac.ir

${ }^{1}$ Department of Medical Entomology and Vector Control, School

of Public Health, Tehran University of Medical Sciences, Tehran, Iran

${ }^{2}$ Center for Research and Training in Skin Diseases and Leprosy, Tehran

University of Medical Sciences, Tehran, Iran

Full list of author information is available at the end of the article
}

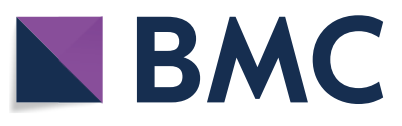

(c) The Author(s) 2021. This article is licensed under a Creative Commons Attribution 4.0 International License, which permits use, sharing, adaptation, distribution and reproduction in any medium or format, as long as you give appropriate credit to the original author(s) and the source, provide a link to the Creative Commons licence, and indicate if changes were made. The images or other third party material in this article are included in the article's Creative Commons licence, unless indicated otherwise in a credit line to the material. If material is not included in the article's Creative Commons licence and your intended use is not permitted by statutory regulation or exceeds the permitted use, you will need to obtain permission directly from the copyright holder. To view a copy of this licence, visit http://creativeco mmons.org/licenses/by/4.0/. The Creative Commons Public Domain Dedication waiver (http://creativecommons.org/publicdomain/ zero/1.0/) applies to the data made available in this article, unless otherwise stated in a credit line to the data. 


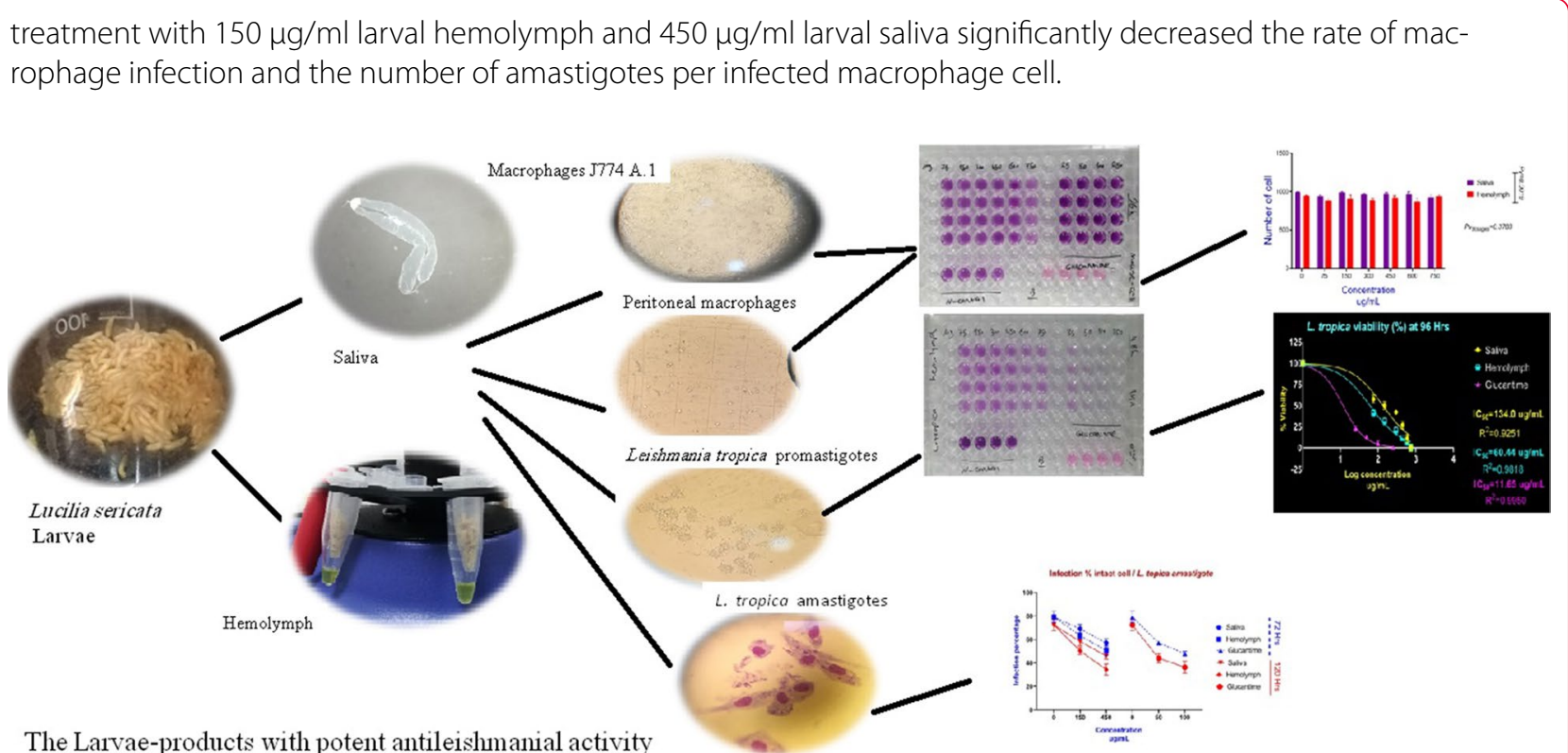

Conclusion: Larval saliva and hemolymph of L. sericata have acceptable leishmanicidal properties against L. tropica.

Keywords: Anti-leishmanial activity, Saliva, Leishmania tropica, Promastigote, Intracellular amastigote, Hemolymph

\section{Introduction}

Leishmaniasis is a vector-borne disease caused by 20 pathogenic Leishmania species and transmitted to humans by about 30 species of female phlebotominae sand flies [1-3]. The World Health Organization (WHO) considers leishmaniasis as 1 of the 7 important infectious diseases and among the 15 most Neglected Tropical Diseases in the world $[1,3]$. Leishmaniasis is endemic in more than 100 countries across four continents. It is estimated that 700,000 to 1.2 million new cases are recorded every year, and about 350 million people are at risk of contracting the infectious disease [2-4].

Clinical manifestations vary from self-healing cutaneous (cutaneous leishmaniasis) lesions to fatal visceral (visceral leishmaniasis) disease depending on the interaction between the Leishmania species and host's immune response $[3,5]$. Cutaneous leishmaniasis (CL) is widely distributed in Afghanistan, Algeria, Brazil, Colombia, Costa Rica, Ethiopia, Peru, Sudan, the Syrian Arab Republic and the Islamic Republic of Iran, where 0.7 million new cases are reported annually $[1,2,6]$. In Iran, Leishmania tropica is the main agent of anthroponotic cutaneous Leishmaniasis (ACL). The ACL form of the disease is endemic in 14 foci in 8 provinces, including Tehran in the central part of the country, Mashhad, Neishabur and Sabzvar in the northeast, Shiraz in the south and Kerman and Bam in the southeast [7-9]. The main vector of $L$. tropica is Phlebotomus sergenti, and the main reservoir host is human but dogs have a role as animal reservoir host, and active lesions in dogs have been reported in Tehran, Mashhad, Shiraz and Neishabur [10].

Due to the toxicity of the current anti-leishmanial drugs, including the antimonials (first-line medication), amphotericin B (AmB) (2nd line medication), imidazoles, miltefosine, paromomycin and liposomal amphotericin $\mathrm{B}$, as well as the emerging resistance, high cost of medications and long duration of the treatment regimen, there have been calls for the development of novel, effective drugs $[11,12]$.

Natural chemical compounds have been suggested as promising candidates for the development of safe and effective drugs against the disease. A large body of evidence has indicated the potential use of some insect products as drug candidates for the treatment of human diseases. The use of insect products as medicines for the treatment of diseases is termed "bugs as drugs" [13, 14].

Maggot therapy has been widely used for the treatment of various kinds of wounds. One of the widely used larvae for maggot therapy is Lucilia sericata [15-17]. The mechanisms of action of maggot therapy involve the removal of necrotic tissues and stimulation of tissue granulation by the larvae. The larvae also exhibit antiseptic effects [18, 19]. Anti-microbial peptides (AMPs) released into the wound through larval excretion and secretions (ES) have microbicidal effects against pathogenic microorganisms such as gram-positive and -negative bacteria [20$24]$, fungi $[25,26]$ and parasites [15, 27, 28]. Among the 
800 AMPs that have been isolated from natural sources (Antimicrobial Peptide Database, http://aps.unmc.edu/ $\mathrm{AP} /$ main.php), approximately half have been derived from insects [14].

Previous studies have investigated the effectiveness of the larval ES in the treatment of CL induced in murine and hamster models using Leishmania amazonesis [29] and in a $L$. major-infected murine model [28]. Also, the effectiveness of the larval ES in in vitro CL models infected with L. tropica [30] and in vivo models infected with Leishmania panamensis [15] has been investigated.

The aim of the present study was to evaluate the antiLeishmania effects of larval saliva and hemolymph of $L$. sericata against $L$. tropica. Also, we analyzed and compared the effectiveness of salivary gland lysate (SGL) of laboratory-bred larvae with field-caught larvae against $L$ tropica. In the present study, the activity of larval products of $L$. sericata on L. tropica promastigotes and intracellular parasites and the cytotoxic activity of larval hemolymph and SGL against the murine macrophage cell line, J774A.1 cells and peritoneal macrophages were evaluated by cell viability assays, and the efficacies of the larval products were compared with Glucantime.

\section{Materials and methods}

\section{Adult fly collection}

The adult flies were caught by hand collection and bait trap methods from different habitats including livestock farms, gardens and slaughterhouses in Tehran County between April-June 2018. Adults were transferred to the insectary of Cyclorrhapha flies at the School of Public Health, Tehran University of Medical Sciences (SPH-TUMS).

In this study, adult flies were anesthetized by cold shock and were then subjected to morphological identification using morphological keys [31]. The field strain of $L$. sericata was reared in a separate place at the insectary to obtain first-generation (F1) larvae. The F1 larvae were reared to the third-instar stage, and their SGL protein profiles were compared with third-instar laboratory-bred larvae using the SDS-PAGE technique. The adult flies were fed with beef liver and meat, which is their preferred medium for egg laying.

\section{Fly rearing}

A laboratory-bred strain of L. sericata was obtained from colonies maintained at the insectary of Cyclorrhapha flies at the SPH-TUMS. These colonies have been grown and maintained in the laboratory since December 2012.

Adult flies were kept and maintained in $46 \times 46 \times$ $46 \mathrm{~cm}$ cages under controlled conditions in a rearing room at $27 \pm 3{ }^{\circ} \mathrm{C}, 45 \pm 5 \%$ relative humidity and $16: 8 \mathrm{~h}$ light/dark [32]. Adult flies were offered granulated sugar, water and palm dates as well as a piece of beef liver to provide the essential carbohydrates and proteins and suitable oviposition surface.

Laid egg batches were transferred to a rearing jar, and newly hatched larvae were fed on beef liver daily. Under the above-mentioned conditions, third-instar larvae appeared on the 3rd day. A 12-mm-long third-instar larva was used as the standard size for all experiments [33].

\section{Sterile larvae preparation}

Larvae were collected from the rearing jars, washed in sterile distilled water, immersed in $4 \%$ deconex and then rinsed three times with sterile distilled water. Finally, the larval specimens were sterilized in 70\% isopropyl alcohol (IPA) and dried on a sterilized napkin. Laboratory tests for bacterial infection were performed before preparation of larva SGLs and hemolymph.

\section{Preparation of salivary gland lysate (SGLs)}

The salivary glands of the third-instar larvae were dissected and transferred into cold fresh phosphate-buffered saline (PBS), $\mathrm{pH}$ 7.2. The salivary gland tissues were then stored at $-20{ }^{\circ} \mathrm{C}$ until use. Before use, salivary glands were disrupted by three cycles of freeze/thaw in liquid nitrogen and boiling water for a few seconds. After the centrifugation of the homogenate at $18,000 \mathrm{~g}$ for $15 \mathrm{~min}$, the SGL supernatants were used for subsequent tests [7, 34].

\section{Protein measurement}

The concentration of SGL proteins was determined by the BCA Protein Assay Kit (Takara Biotechnology, no. T9300A, Japan), following the manufacturer's instructions. Standard proteins were prepared from bovine serum albumin (BSA) in sodium azide.

\section{Preparation of larval hemolymph}

The anterior part of the third-instar larvae (near the mouth hooks) was cut using small scissors. Each $0.5-\mathrm{ml}$ micro-tube was cut about 3-4 $\mathrm{mm}$ straight down the center using a razor blade, and batches of ten larvae were put in $0.5-\mathrm{ml}$ micro-tubes. Finally, each of the prepared 0.5 - $\mathrm{ml}$ tubes was placed in a larger $1.5-\mathrm{ml}$ micro-tube for centrifugation for 5-10 s to isolate the hemolymph from the larvae. This step was performed immediately before use of the hemolymph to prevent melanization of the hemolymph product.

\section{SDS-PAGE}

Larval SGLs of $L$. sericata were extracted, and the proteins and/or glycoproteins were visualized by SDS-PAGE on 1 -mm-thick $12.5 \%$ Tris-glycine gel with $110-\mathrm{V}$ fixed 
voltage using "Mini-Protein III" (Bio-Rad, Munich, Germany) under reducing conditions.

The SGLs from three to five pooled glands were loaded into each well. Following electrophoresis, the gels were stained with silver nitrate according to the methods described by Heukeshoven and Dernick [35]. A prestained protein ladder (PageRuler, Fermentas) was used to estimate the molecular weights of the protein bands.

\section{Parasite culture}

Promastigotes of $L$. tropica (MHOM/IR/01/YAZA) were obtained from patients referred to the Center for Research and Training in Skin Diseases and Leprosy (CRTSDL) of TUMS for treatment of CL infection. The amastigotes were grown in Novy-Macneal-Nicolle (NNN) medium and sub-cultured in RPMI 1640 supplemented with 10\% heat-inactivated fetal bovine serum (FBS), penicillin and streptomycin $(100 \mu \mathrm{g} / \mathrm{ml})$ at $26 \pm 1{ }^{\circ} \mathrm{C}$.

\section{Culture of the murine macrophage cell line, J774A.1 cells}

The J774A.1 cells were obtained from the National Cell Bank of Iran (Pasteur Institute, Tehran, Iran) and cultured in DMEM medium supplemented with 15\% FBS, penicillin and streptomycin $(100 \mu \mathrm{g} / \mathrm{ml})$ at $37{ }^{\circ} \mathrm{C}$ in a $5 \%$ $\mathrm{CO}_{2}$ humidified incubator.

\section{Culture of murine peritoneal macrophages}

Peritoneal cells were collected from the peritoneal cavity of 4-5-week-old female BALB/c mice. For this purpose, each mouse was injected intraperitoneally (IP) with $3 \mathrm{ml}$ of sterile $3 \%$ thioglycollate medium and then anesthetized by IP injection of sodium pentobarbital $(100 \mathrm{mg} / \mathrm{kg})$ after $72 \mathrm{~h}$.

The anesthetized mice were killed by cervical dislocation. The whole body of each mouse was washed using $70 \%$ ethanol; $5 \mathrm{ml}$ cold PBS was injected into the peritoneal cavity of each mouse. Following PBS injection, the peritoneal cells were aspirated. The cell suspension was centrifuged for $10 \mathrm{~min}$ at $400 \mathrm{~g}$ in a refrigerated centrifuge and resuspended in RPMI 1640 supplemented with $15 \%$ FBS. The cells were then incubated at $37{ }^{\circ} \mathrm{C}$ in a $5 \% \mathrm{CO}_{2}$ incubator. After incubation, the cells were counted, and the viability of the cells was assessed.

\section{Leishmania tropica promastigote susceptibility to larval saliva and hemolymph of $L$. sericata}

Promastigotes of L tropica were harvested at log-phase, and $1 \times 10^{5}$ parasites per well were cultured on a 96-well plate using complete RPMI 1640 medium. Then, larval saliva or hemolymph was added at $75,150,300,450,600$ and $750 \mu \mathrm{g} / \mathrm{ml}$ concentrations and incubated at $26 \pm 1{ }^{\circ} \mathrm{C}$ for $24,48,72$ and $96 \mathrm{~h}$.
The number of viable parasites was determined by direct observation under the light microscope and 3-(4.5-dimethylthiazol-2-yl)-2,5-diphenyltetrazolium bromide (MTT) assay. Briefly, MTT $(0.5 \mathrm{mg} / \mathrm{ml})$ was dissolved in saline solution, and the solution was further sterilized using $0.22-\mathrm{mm}$ filters.

About 200 ul of MTT solution was added to each well and incubated at $26 \pm 1{ }^{\circ} \mathrm{C}$ for an additional $4 \mathrm{~h}$. The supernatant was gently removed, and the formazan crystals were solubilized by $100 \mu$ l dimethyl sulfoxide (DMSO). The optical density (OD) of the plates was determined using the ELISA reader (Bio-Tek ELX $808 \mathrm{iu}$ ) at 570/630 $\mathrm{nm}$ [36].

Different concentrations of Glucantime (25, 50,100, $250 \mu \mathrm{g} / \mathrm{ml}$ ) were used as positive controls and sterile PBS were used as a negative control. All the experiments were performed in quadruplicate, and the results were compared with the negative and positive controls.

\section{Cytotoxicity test for larval products against peritoneal} macrophages and murine macrophage cell line, J774 cells

The peritoneal macrophages and J774 cells were plated at $1 \times 10^{5}$ and $5 \times 10^{4}$ cells per well, respectively, on a 96-well culture plate in complete RPMI 1640 medium at $37{ }^{\circ} \mathrm{C}$ and $5 \% \mathrm{CO}_{2}$ condition. Following bonding time, the larval products were added at concentrations of 75, 150, $300,450,600$ and $750 \mu \mathrm{g} / \mathrm{ml}$. Cells with and without treatment were incubated at $37^{\circ} \mathrm{C}$ for $24,48,72,96$ and $120 \mathrm{~h}$.

The number of viable cells (cell viability assay) was determined by direct observation trypan blue test and 3-(4.5-dimethylthiazol-2-yl)-2,5-diphenyltetrazolium bromide (MTT) assay. The trypan blue dye exclusion test distinguishes dead cells from viable cells by color change. The MTT assay was similar to what we described in the parasite viability assay.

The values of $50 \%$ cytotoxicity concentration $\left(\mathrm{CC}_{50}\right)$ and $50 \%$ inhibitory concentration $\left(\mathrm{IC}_{50}\right)$ were calculated by non-linear regression tests, and the selectivity index (SI) was determined by the $\mathrm{CC}_{50} / \mathrm{IC}_{50}$ ratio [37].

\section{Amastigote susceptibility to larval saliva and hemolymph of $L$. sericata}

The peritoneal macrophages and J774 cells were dispensed in an eight-well chamber slide at $7 \times 10^{4}$ and $2 \times 10^{4}$ cells/well, respectively, and the samples were incubated at $37^{\circ} \mathrm{C}, 5 \% \mathrm{CO}_{2}$ for $6 \mathrm{~h}$ to allow the adherence of cells.

The adherent cells were washed with warm RPMI medium, then infected with stationary-phase L. tropica promastigote at 10:1 parasite/cell and incubated again in complete RPMI medium. After $24 \mathrm{~h}$, the infected cells 
Table 1 Parameters for evaluating amastigote susceptibility to larval-derived products

\begin{tabular}{|c|c|c|}
\hline Parameter & Abbreviation & Equation \\
\hline Infection percentage & $1 \%$ & (\# Infected cells/100 randomly chosen cells) × 100 \\
\hline Decreased in infection percentage & DI \% & {$[(\% /$ no treatment $-\% /$ treatment $) / \% /$ no treatment $] \times 100$} \\
\hline Viability of amastigote percentage & V\% & (\# amastigote treatment/\# amastigote no treatment) $\times 100$ \\
\hline Decreased viability of amastigote percentage & DV \% & $\begin{array}{l}\text { [(\# amastigote no treatment }-(\# \text { amastigote treatment/no } \\
\quad \text { treatment }] \times 100\end{array}$ \\
\hline Parasite load & $\mathrm{PL}$ & \# amastigotes/\# infected cells \\
\hline Survival index & SVI & $\% / \times P L$ \\
\hline Selectivity index & $\mathrm{SI}$ & $\mathrm{CC}_{50} / \mathrm{IC}_{50}$ \\
\hline
\end{tabular}

were gently washed with warm RPMI medium to remove non-internalized promastigotes and were then treated with larval products at a concentration of 150 and 450 $\mu \mathrm{g} / \mathrm{ml}$ in triplicate for 72 and $120 \mathrm{~h}$.

Glucantime was used as positive control (standard drug), and macrophages containing amastigotes without treatment were used as negative controls.

Finally, each slide was dried, fixed and stained with Giemsa staining. The stained slides were examined under light microscope. The percentage of infected macrophages and mean number of amastigotes per 100 macrophages were calculated and compared with the untreated control group.

\section{Statistical analysis}

Continuous baseline demographic and in vitro data have been presented as mean \pm standard deviation (SD) and grouped data as frequencies and percentages. Departure from normality assumption was assessed by the Kolmogorov-Smirnov test.

Chi-square and/or Fisher's exact tests were used to determine the independence of two categorical variables.

A paired $T$-test was used to evaluate the differences in mean within each treatment group. The utilized assumptions of the parametric statistics were conformed to the data by checking the data normality.

One-way ANOVA followed by Bonferroni multiple comparison tests was employed to investigate the differences in mean between the different groups. To investigate the differences between parasite and macrophage cell fatality under different treatments, $t$ concentrations and time points, we used the generalized estimation equation (GEE) method developed by Liang and Zeger.

The GEE is a widely used estimation method for marginal (i.e. population-averaged) modeling of repeated data. In brief, GEEs use the generalized linear model to estimate more efficient and unbiased regression parameters relative to ordinary least square regression in part, because they permit specification of a working

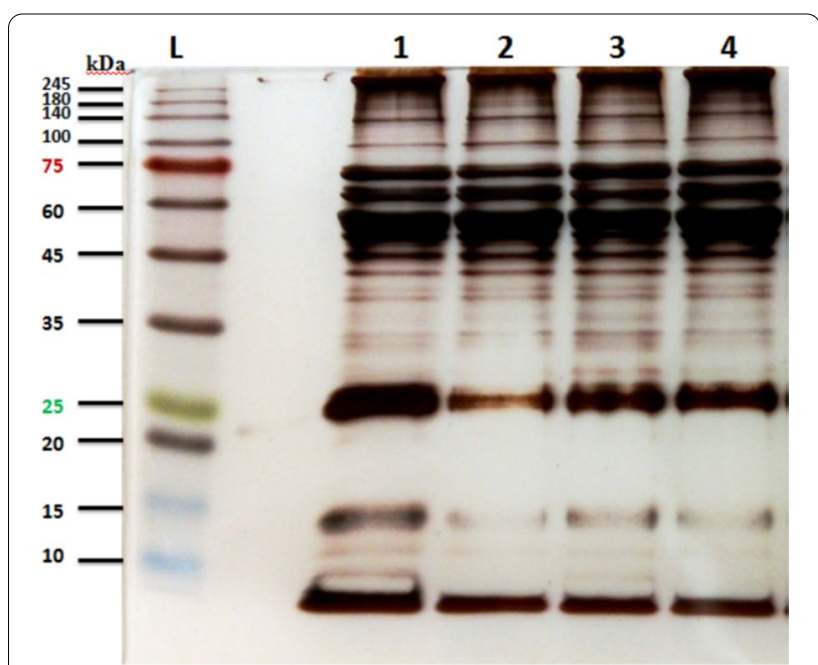

Fig. 1 SDS-PAGE analyses of salivary gland lysates of field- and laboratory-bred L. sericata third-instar larvae. L: pre-stained protein ladder (page-ruler); lanes 1 and 2: laboratory-bred larvae; lanes 3 and 4: field larvae collected from Tehran Province, Iran

correlation matrix that accounts for the form of withinsubject correlation of responses on dependent variables of many different distributions, including normal, binomial, and Poisson.

The GraphPad Prism's (8.0.2) dose-response (variable slope) equation [log (inhibitor) vs normalized response] was used to estimate the CC50 and IC50 values of the larval products against both of the macrophage cell types and $L$. tropica promastigotes.

Infection rate $(\% I)$, decrease in infection rate $(\% \mathrm{DI})$, viability percentage of amastigotes $(\% V)$, percent decrease in viability of amastigotes (\%DV), parasite load, survival index and selectivity index were defined for analyzing the amastigote and promastigote susceptibility to the larval products and toxicity of the larval products to the macrophage cell types (Table 1 ). 

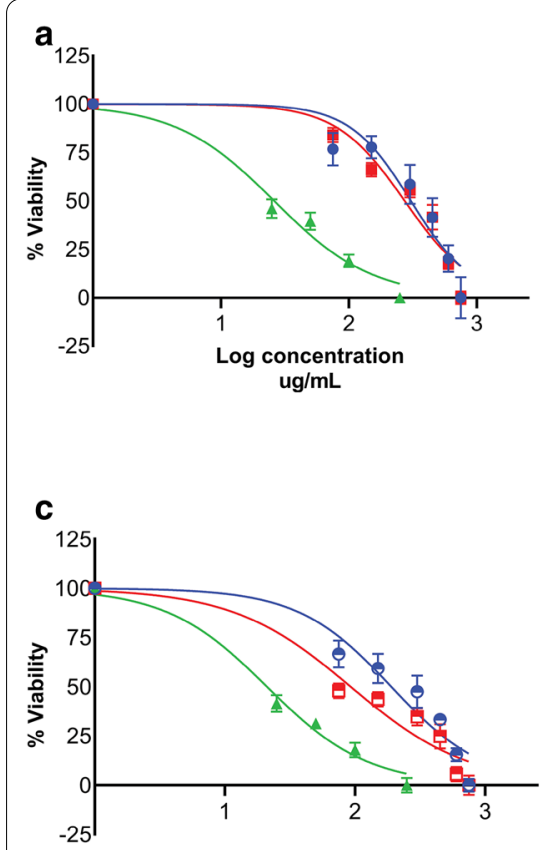

$$
\begin{aligned}
& \text { - Saliva } \\
& \text { - Hemolymph } \\
& \text { * Glucantime } \\
& \mathrm{IC}_{50}=\mathbf{3 0 9} \mathrm{ug} / \mathrm{mL} \\
& \mathrm{R}^{2}=0.8702 \\
& \mathrm{IC}_{50}=\mathbf{2 7 3} \mathrm{ug} / \mathrm{mL} \\
& \mathrm{R}^{2}=0.9172 \\
& \mathrm{IC}_{50}=26.06 \mathrm{ug} / \mathrm{mL} \\
& \mathrm{R}^{2}=0.9681
\end{aligned}
$$

$$
\begin{aligned}
& \text { - Saliva } \\
& \text { E Hemolymph } \\
& \text { t Glucantime } \\
& I C_{50}=190.2 \mathrm{ug} / \mathrm{mL} \\
& \mathrm{R}^{2}=0.9128 \\
& I C_{50}=92.76 \mathrm{ug} / \mathrm{mL} \\
& \mathrm{R}^{2}=0.9279 \\
& I C_{50}=18.45 \mathrm{ug} / \mathrm{mL} \\
& \mathrm{R}^{2}=0.9829
\end{aligned}
$$

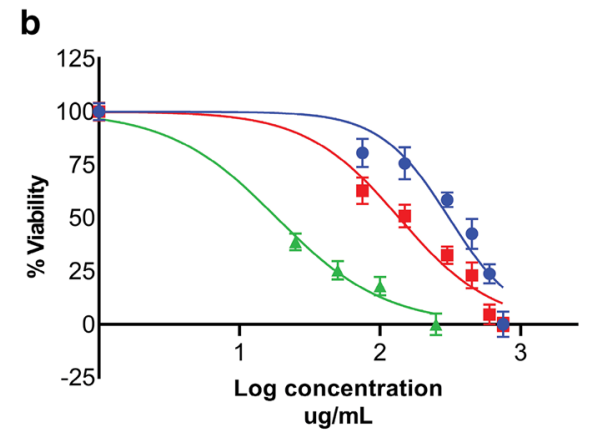

d

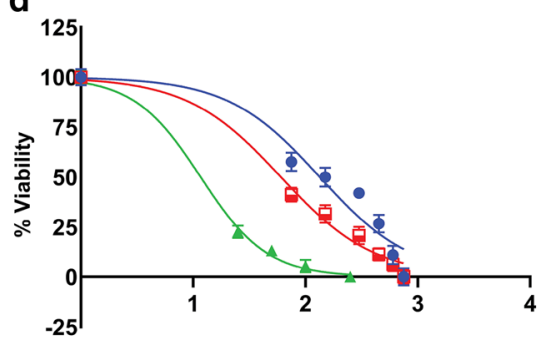

- Saliva

- Hemolymph

- Glucantime

$\mathrm{IC}_{50}=305.7 \mathrm{ug} / \mathrm{mL}$ $R^{2}=0.9131$

$\mathrm{IC}_{50}=136.8 \mathrm{ug} / \mathrm{mL}$ $\mathrm{R}^{2}=0.9559$

$I_{50}=21.05 \mathrm{ug} / \mathrm{mL}$ $\mathrm{R}^{2}=0.9835$

$$
\begin{aligned}
& \text { - Saliva } \\
& \text { * Hemolymph } \\
& \text { * Glucantime } \\
& I_{I_{50}}=134.0 \mathrm{ug} / \mathrm{mL} \\
& \mathrm{R}^{2}=0.9251 \\
& \mathrm{IC}_{50}=60.44 \mathrm{ug} / \mathrm{mL} \\
& \mathrm{R}^{2}=0.9818 \\
& I C_{50}=11.65 \mathrm{ug} / \mathrm{mL} \\
& \mathrm{R}^{2}=0.9950
\end{aligned}
$$

Fig. 2 Dose-response curves regarding the effect of Lucilia sericata larval-derived products on Leishmania tropica promastigotes $\left(I \mathrm{C}_{50}\right)$. a Larval saliva IC 50 vs larval hemolymph IC 50 at $24 \mathrm{~h}$. b Larval saliva IC $\mathrm{C}_{50}$ vs larval hemolymph IC 50 at $48 \mathrm{~h}$. $\mathbf{c}$ Larval saliva IC 50 vs larval hemolymph IC 50 at $72 \mathrm{~h}$. d Larval saliva $\mathrm{IC}_{50}$ vs larval hemolymph $\mathrm{IC}_{50}$ at $96 \mathrm{~h}$ and compared with standard drug

STATA version $13 \mathrm{MP}$ was used to perform all the statistical analyses, and $p$ values $\leq 0.05$ were considered statistically significant.

\section{Results \\ Protein concentration of larval salivary gland and hemolymph of $L$. sericata}

The average protein contents of one pair of larval salivary glands were 5.7 and $14.7 \mu \mathrm{g}$ for field- and laboratory-bred L. sericata larvae, respectively. The average protein contents of larval hemolymph isolated from $L$. sericata specimens were 213 and $314 \mu \mathrm{g}$ for field- and laboratory-bred larvae, respectively.

\section{Salivary gland protein profiles of the Lucilia sericata larvae}

About 17-19 protein bands were observed in the $12.5 \%$ polyacrylamide gel, with molecular weight of 10-245 $\mathrm{kDa}$. The electrophoretic protein patterns of SGL proteins of field- and laboratory-bred L. sericata larvae are shown in Fig. 1.

The SGL proteins of field- and laboratory-bred larvae were separated into ten major protein bands with molecular masses of $15-140 \mathrm{kDa}$ and 8 faint bands of about $12-15$ and $27-42 \mathrm{kDa}$ in both field- and laboratory-bred larvae. Interestingly, the SGL profiles of field third-instar

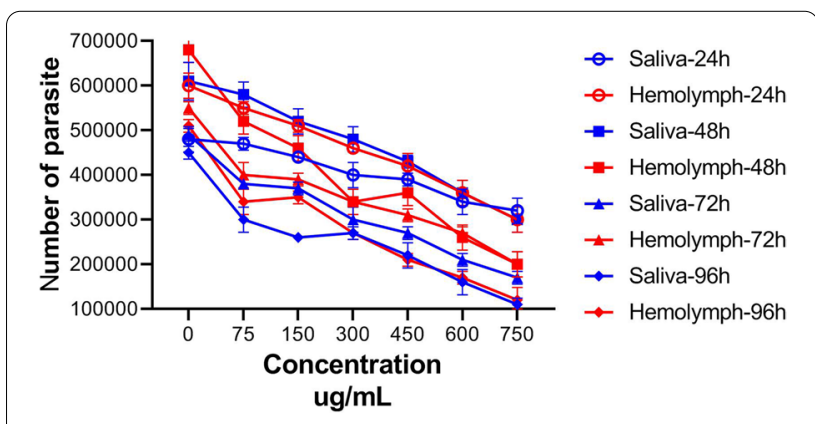

Fig. 3 The number of alive promastigotes exposed to larval-derived products in different dosages at different time points

Table 2 Selectivity index for Leishmania tropica promastigote treatment with saliva and hemolymph at different time points

\begin{tabular}{lllll}
\hline Treatment & \multicolumn{5}{l}{ Selectivity } & index $\left(\mathrm{CC}_{50} / \mathrm{IC}_{50}\right)$ & & \\
\cline { 2 - 5 } Time: & $24 \mathrm{~h}$ & $48 \mathrm{~h}$ & $72 \mathrm{~h}$ & $96 \mathrm{~h}$ \\
\hline Saliva & 2.38 & 2.42 & 3.94 & 5.59 \\
Hemolymph & 2.74 & 5.48 & 8.08 & 12.4 \\
\hline
\end{tabular}

larvae were completely similar to those of the laboratorybred third-instar larvae. 

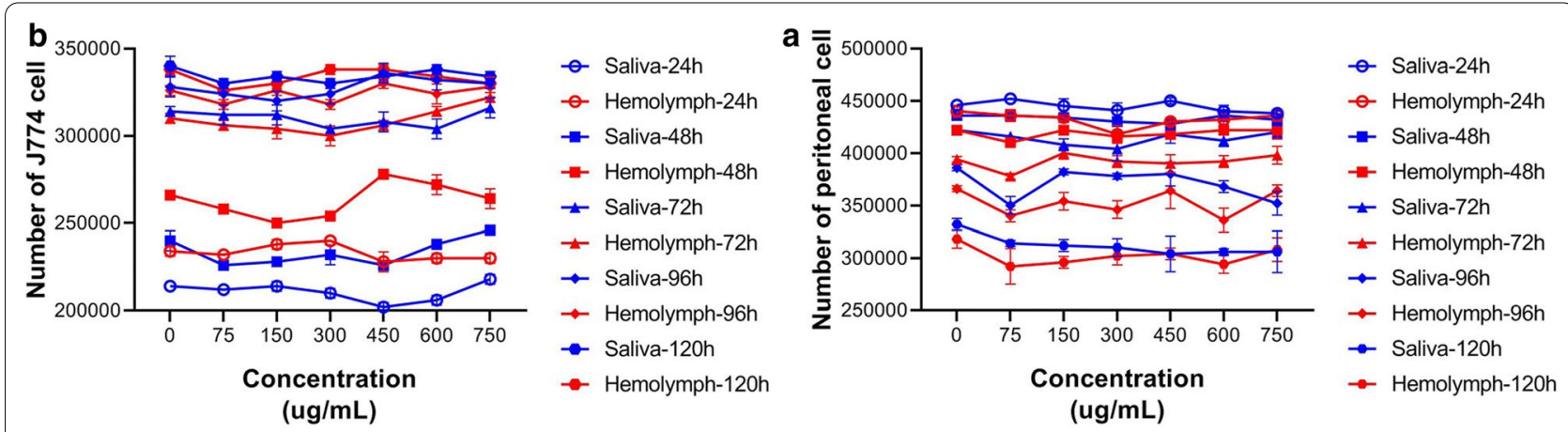

Fig. 4 The number of viable cells treated with larval-derived products by trypan blue in different dosages at different time points. a The number of peritoneal viable cells treated with larva-derived products in different concentrations at different time points. b The number of 5774 viable cells treated with larva-derived products in different concentrations at different time points

Table 3 Effect of Lucilia sericata larval-derived products on Leishmania tropica amastigote in in vitro conditions

\begin{tabular}{|c|c|c|c|c|c|c|c|c|c|}
\hline \multirow{3}{*}{$\begin{array}{l}\text { Treatment } \\
\text { Time (h) }\end{array}$} & \multirow[t]{3}{*}{ Dosages $(\mu \mathrm{g} / \mathrm{ml})$} & \multicolumn{4}{|c|}{ Amastigote L. tropica/peritoneal cell } & \multicolumn{4}{|c|}{ Amastigote L. tropica/J774 cell line } \\
\hline & & \multicolumn{2}{|l|}{$1 \%$} & \multicolumn{2}{|l|}{ V\% } & \multicolumn{2}{|l|}{$1 \%$} & \multicolumn{2}{|l|}{ V\% } \\
\hline & & $72 \mathrm{~h}$ & $120 \mathrm{~h}$ & $72 \mathrm{~h}$ & $120 \mathrm{~h}$ & $72 \mathrm{~h}$ & $120 \mathrm{~h}$ & $72 \mathrm{~h}$ & $120 \mathrm{~h}$ \\
\hline No treatment control & 0 & $79.3 \pm 4.7$ & $72.3 \pm 4.7$ & $100 \pm 0$ & $100 \pm 0$ & $66.3 \pm 4$ & $59 \pm 3.6$ & $100 \pm 0$ & $100 \pm 0$ \\
\hline \multirow[t]{2}{*}{ Saliva } & 150 & $69 \pm 4$ & $58.3 \pm 3.5$ & $74.2 \pm 2$ & $53.1 \pm 2.3$ & $58 \pm 4$ & $35 \pm 2.6$ & $67.5 \pm 3.2$ & $48.7 \pm 3.3$ \\
\hline & 450 & $57 \pm 3.6$ & $46 \pm 3$ & $69.5 \pm 2.7$ & $47.7 \pm 3.1$ & $51.3 \pm 1.5$ & $26.3 \pm 2.5$ & $62.4 \pm 3.2$ & $39 \pm 3.8$ \\
\hline \multirow[t]{2}{*}{ Hemolymph } & 150 & $63.3 \pm 2.5$ & $50.3 \pm 3.2$ & $64.5 \pm 3$ & $42.8 \pm 3.4$ & $56 \pm 4.4$ & $22 \pm 4$ & $56.6 \pm 3.9$ & $38.4 \pm 2$ \\
\hline & 450 & $50.7 \pm 4$ & $34.3 \pm 4.7$ & $57.7 \pm 4$ & $35.9 \pm 2.8$ & $40.3 \pm 3.1$ & $15 \pm 3$ & $48.7 \pm 2.6$ & $26.6 \pm 2.8$ \\
\hline Positive control & 50 & $57 \pm 1$ & $44 \pm 4$ & $66.9 \pm 2.7$ & $49.3 \pm 2.8$ & $47.3 \pm 3.8$ & $27.3 \pm 2.5$ & $60.3 \pm 2.7$ & $45.7 \pm 1.9$ \\
\hline Glucantime & 100 & $48 \pm 2$ & $36.3 \pm 5.1$ & $55.4 \pm 2.5$ & $35.7 \pm 3.1$ & $36 \pm 2.6$ & $13.3 \pm 3.2$ & $46.2 \pm 4$ & $34 \pm 3.3$ \\
\hline
\end{tabular}

1\%: infection percentage; $V \%$ : viability of amastigote

\section{Leishmania tropica promastigote susceptibility to larval products of $L$. sericata}

The $\mathrm{IC}_{50}$ values of larval saliva and hemolymph of Lucilia sericata were evaluated against parasite promastigotes at 24, 48, 72 and $96 \mathrm{~h}$.

The lowest $\mathrm{IC}_{50}$ values were $134.0 \mu \mathrm{g} / \mathrm{ml}(\log =2.127)$ and $60.44 \mu \mathrm{g} / \mathrm{ml}(\log =1.781)$ at $96 \mathrm{~h}$ for the larval saliva and hemolymph, respectively. The results were compared with those of Glucantime (Fig. 2).

Statistically significant differences in the viability percentage of promastigotes were observed for both larval saliva and hemolymph at different doses compared with the negative control $(p \leq 0.0001)$. Also, there was a statistically significant difference in viability percentage of promastigotes treated with saliva compared with Glucantime $(p=0.0001)$, but the difference was not significant between hemolymph and Glucantime $(p=0.806)$.

MTT assay showed strong toxicity of the larval products against promastigotes, which increased with an increase in concentration. The lowest viability percentage was $24 \%$ for promastigotes treated with saliva and $11 \%$ for promastigotes treated with hemolymph. However, treatment with very high concentrations of larval products for $120 \mathrm{~h}$ had no toxic effect on both types of macrophages, with cell viability of both types of macrophages $>95 \%$.

Figure 3 illustrates the number of live parasite promastigotes observed directly under the light microscope. The selectivity indexes (SI) of L. sericata larval products are showed in Table 2.

\section{Cytotoxicity of larval products of Lucilia sericata to peritoneal macrophages and murine macrophage cell line and $\mathbf{J 7 7 4}$ cells}

The number of viable cells was obtained for both types of macrophages at 24, 48, 72, 96 and $120 \mathrm{~h}$ (Fig. 4). The viability percentage of macrophages was estimated by using the MTT assay at the time points specified above after exposure to larval saliva and hemolymph.

MTT assays showed that larval saliva and hemolymph did not have any significant toxic effect on either mouse peritoneal macrophages or J774 cells in different doses and time points. There were no significant differences in 


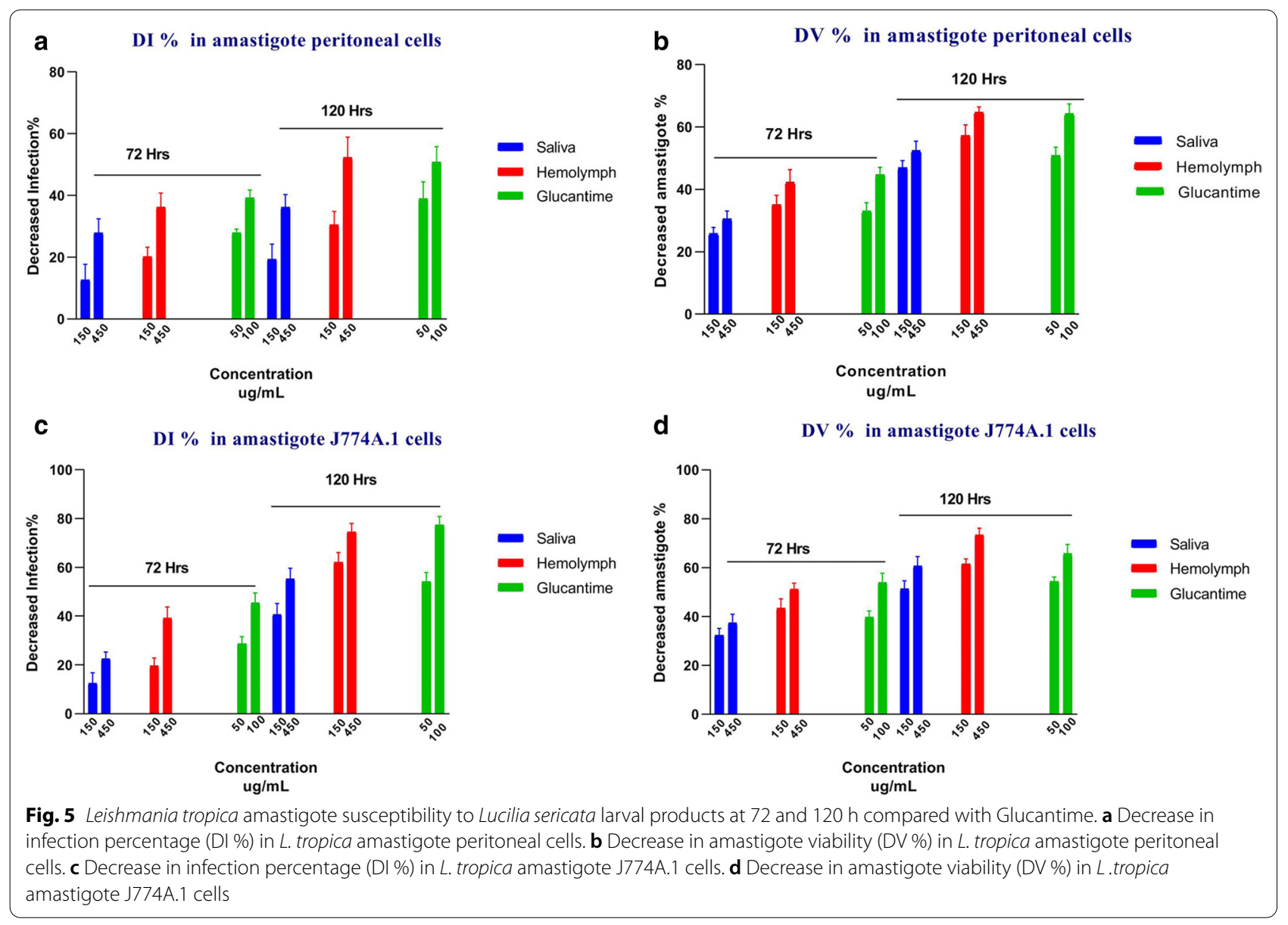

Table 4 Parameters for evaluating amastigote Leishmania tropica peritoneal macrophage susceptibility to larval-derived products

\begin{tabular}{|c|c|c|c|c|c|}
\hline \multirow[t]{2}{*}{ Treatment } & \multirow[t]{2}{*}{ Dosages $(\mu \mathrm{g} / \mathrm{ml})$} & \multicolumn{2}{|l|}{$P L$} & \multicolumn{2}{|l|}{ SVI } \\
\hline & & $72 \mathrm{~h}$ & $120 \mathrm{~h}$ & $72 \mathrm{~h}$ & $120 \mathrm{~h}$ \\
\hline No treatment control & 0 & $2.70 \pm 0.70$ & $3.05 \pm 0.57$ & $213.3 \pm 4.70$ & $219.6 \pm 4.7$ \\
\hline \multirow[t]{2}{*}{ Saliva } & 150 & $2.28 \pm 0.81$ & $2.0 \pm 0.62$ & $157.3 \pm 2.81$ & $116 \pm 3.5$ \\
\hline & 450 & $2.14 \pm 0.67$ & $1.81 \pm 0.75$ & $121.9 \pm 3.6$ & $83.2 \pm 3$ \\
\hline \multirow[t]{2}{*}{ Hemolymph } & 150 & $2.17 \pm 0.80$ & $1.86 \pm 0.35$ & $136.7 \pm 2.5$ & $93 \pm 3.2$ \\
\hline & 450 & $1.95 \pm 0.25$ & $1.58 \pm 0.97$ & $97.5 \pm 4.2$ & $53.7 \pm 4.2$ \\
\hline Positive control-Glucantime & 50 & $2.16 \pm 0.50$ & $1.86 \pm 0.40$ & $123.1 \pm 5.7$ & $81.8 \pm 4$ \\
\hline
\end{tabular}

PL parasite load, SVI survival index

the viability percentage of both macrophage types when treatments with larval saliva, hemolymph and Glucantime were compared $(p=0.439)$. However, there was a significant difference in cell viability percentage between the two types of macrophages $(p=0.0001)$ after treatment with all three treatments.

\section{Amastigote susceptibility to larval saliva and hemolymph of $L$. sericata}

The infection rate $(I \%)$, viability percentage of amastigotes $(V \%)$, decrease in infection rate $(\mathrm{DI} \%)$ and percent decrease in amastigote viability (DV\%) of both treatments with saliva and hemolymph are summarized in Table 3 and Fig. 5.

The infection rate and percentage of viable amastigotes significantly decreased after treatment with larval 
Table 5 Parameters for evaluating amastigote Leishmania tropica J774A.1 macrophage susceptibility to larval-derived products

\begin{tabular}{|c|c|c|c|c|c|}
\hline \multirow[t]{2}{*}{ Treatment } & \multirow[t]{2}{*}{ Dosages $(\mu \mathrm{g} / \mathrm{ml})$} & \multicolumn{2}{|l|}{$\mathrm{PL}$} & \multicolumn{2}{|l|}{ SVI } \\
\hline & & $72 \mathrm{~h}$ & $120 \mathrm{~h}$ & $72 \mathrm{~h}$ & $120 \mathrm{~h}$ \\
\hline No treatment control & 0 & $2.16 \pm 0.31$ & $2.03 \pm 0.31$ & $142.6 \pm 8$ & $120 \pm 10$ \\
\hline \multirow[t]{2}{*}{ Saliva } & 150 & $2.26 \pm 0.47$ & $1.55 \pm 0.28$ & $131.0 \pm 5$ & $54.2 \pm 4$ \\
\hline & 450 & $2.22 \pm 0.33$ & $1.41 \pm 0.50$ & $113.2 \pm 4$ & $36.6 \pm 3$ \\
\hline \multirow[t]{2}{*}{ Hemolymph } & 150 & $1.88 \pm 0.63$ & $1.38 \pm 0.44$ & $99.6 \pm 5$ & $30.3 \pm 3$ \\
\hline & 450 & $1.77 \pm 0.51$ & $1.20 \pm 0.17$ & $70.8 \pm 4$ & $18 \pm 2$ \\
\hline \multirow[t]{2}{*}{ Positive control-Glucantime } & 50 & $2.30 \pm 0.39$ & $1.70 \pm 0.80$ & $108.1 \pm 7$ & $45.9 \pm 3$ \\
\hline & 100 & $2.18 \pm 0.75$ & $1.50 \pm 0.62$ & $78.4 \pm 6$ & $19.5 \pm 5$ \\
\hline
\end{tabular}

PL parasite load, SVI survival index

products for 72 and $120 \mathrm{~h}$ compared to the control group $(p=0.0001)$. A statistically significant difference in the rate of macrophage infection and the number of amastigotes per infected macrophage cell was observed between treatment with saliva and Glucantime $(p=0.050)$, but the difference was not significant between treatment with hemolymph and Glucantime $(p=0.880)$.

Based on this result, treatment with $L$. sericata larval products decreased $I \%$ and $V \%$ at higher concentrations and time points $(p=0.003)$ (Table 3). In other words, treatment with higher concentrations of larval products and at higher time points increased the DI\% and DV\% values (Fig. 5). There were no statistically significant differences in DI\% and DV\% between treatment with hemolymph at 150 or $450 \mu \mathrm{g} / \mathrm{ml}$ and Glucantime at $50 \mu \mathrm{g} /$ $\mathrm{ml}(p=0.321)$ as well as treatment with hemolymph at $450 \mu \mathrm{g} / \mathrm{ml}$ and Glucantime at $100 \mu \mathrm{g} / \mathrm{ml}(p=0.408)$.

The average parasite load was $2.12 \pm 0.56$ amastigotes/peritoneal cell (ama/type of cell) when the macrophages were treated with $100 \mu \mathrm{g} / \mathrm{ml}$ of glucantime (positive control) for $72 \mathrm{~h}$. The average parasite load decreased to $1.77 \pm 0.34$ after $120 \mathrm{~h}$. For the negative control group, the parasite load was $2.70 \pm 0.70$ and $3.05 \pm 0.57 \mathrm{ama} /$ peritoneal cell at 72 and $120 \mathrm{~h}$, respectively. Treatment with $450 \mu \mathrm{g} / \mathrm{ml}$ of hemolymph resulted in $1.58 \pm 0.97 \mathrm{ama} /$ peritoneal cell and $1.20 \pm 0.17 \mathrm{ama} / \mathrm{J} 774$ cell at $120 \mathrm{~h}$, which were lower compared with the standard drug (Tables 4,5 ).

The survival index for the standard drug treatment group was $63.7 \pm 5.1$ and $19.5 \pm 5(219.6 \pm 4.7$ and $120 \pm 10$ for the negative control) for amastigotes of $L$. tropica/peritoneal cells and J774 cells at $120 \mathrm{~h}$. Treatment with $450 \mu \mathrm{g} / \mathrm{ml}$ hemolymph reduced the SI to $53.7 \pm 4.2$ and $18 \pm 2$ compared with the negative control at $120 \mathrm{~h}$ (Tables 4,5).

\section{Discussion}

The current study demonstrated the leishmanicidal effects of larval saliva and hemolymph against promastigotes and amastigotes of L. tropica, the causative agent of ACL. This study also evaluated the $\mathrm{IC}_{50}$ and $\mathrm{CC}_{50}$ of larval saliva and hemolymph of $L$. sericata against peritoneal macrophages and the murine macrophage cell line, J774A.1 cells.

Many studies that evaluated the susceptibility and cytotoxicity of $L$. tropica and macrophages to the larval ES of L. sericata. However, to our knowledge, there is no study on the effects of larval saliva and hemolymph of $L$. sericata on L. tropica and macrophage cells.

A previous study that investigated Calliphora vicinia and $L$. sericata larval ES product on the J774 cell line and L. major reported that larval ES product concentrations $>40 \%$ were highly toxic to macrophages [28], but in the current study, higher concentrations of larval saliva and hemolymph had no toxic effect on both types of macrophage cells up to $120 \mathrm{~h}$, with cell viability $>95 \%$. On the other hand, larval saliva and hemolymph of $L$. sericata had more toxic effects on L. tropica promastigotes.

A similar result was reported by another study which demonstrated a greater lethal effect on promastigotes than macrophage cells [38]. Also, the finding of a previous study supports the present finding that larval products have an inhibitory effect on L. tropica promastigote and amastigote forms [30].

In the present study, larval hemolymph was found to be highly toxic to promastigotes compared with larval saliva. The viability percentage of promastigotes was < $15 \%$ when treated with hemolymph for $96 \mathrm{~h}$. This finding is also in agreement with a previous study that evaluated hemolymph toxicity on gram-positive and -negative bacteria. The previous study found that $L$. sericata larval hemolymph had a stronger toxic effect against gram-positive and -negative bacteria than whole-body extract [39]. 
Both $L$. sericata larval products had strong leishmanicidal effects against intracellular amastigotes of $L$. tropica. Treatment with larval products resulted in a decrease in infection rate $(I \%)$ and parasite load, the effect being even stronger for hemolymph treatment than the standard drug $(p=0.880)$.

The decrease in infection rate was $>50 \%$ when treated with $150 \mu \mathrm{g} / \mathrm{ml}$ larval hemolymph and $450 \mu \mathrm{g} / \mathrm{ml}$ larval saliva, but even at these concentrations, no toxic effect was exhibited on both types of macrophages exposed to the larval products. The cell viability of the macrophage cells was $>95 \%$ when treated with $450 \mu \mathrm{g} / \mathrm{ml}$ hemolymph.

Based on the results of the present study, larval products, especially hemolymph, had high toxicity against the leishmania parasites at concentrations that are not cytotoxic to macrophage cells, which is in line with the study carried out by Laverde-Paz et al. [27].

The leishmanicidal effect of the larval products against amastigotes even at low concentration is a promising outcome for future in vivo model experiments. Analysis of the susceptibility of intracellular forms of L. tropica to the larval products showed that treatment with lower concentrations for a longer time period had a more toxic effect on the viability of the parasites. It is worth noting that treatment with higher concentrations of larval products resulted in a decrease in the survival index of the parasites.

This finding is not in agreement with that of previous studies $[27,28]$, which evaluated the susceptibility of the mouse macrophage cell line (J774 cells) infected with amastigotes of L. major and U937 human cell line infected with amastigotes of $L$. panamensis to the larval ES of blowfly species. The difference could be explained by comparing the different components and effective substances in the larval-secretion/excretion (ES) used in the previous study and the larval saliva and hemolymph in the present study.

In the present study, the minimum amastigote viability percentage $(V \%)$ was $35.9 \pm 2.8$ when treated with $450 \mu \mathrm{g} / \mathrm{ml}$ larval-hemolymph and $26.6 \pm 2.8$, which performed similarly to Glucantime $100 \mu \mathrm{g} / \mathrm{ml}$ at $120 \mathrm{~h}$. There were differences in $I, V, \mathrm{DI}$ and DV\% between the two types of macrophage cells $(p=0.0001)$. This may be due to the genetic manipulation of the J774 macrophage cells, which might have resulted in gain or loss of function of genes.

In the present study, the survival index was determined along with the infection rate $(I \%)$. The PL and SVI index values after treatment with hemolymph were lower compared with saliva in both types of macrophage cells infected with $L$. tropica. Also, there was a significant decrease in the PL and SVI index between the larval product treatment groups compared with the no treatment control; furthermore, the leishmanicidal effects of larval products were retained as the duration and concentration increased.

The larval hemolymph was the most selective $(\mathrm{SI}>5)$; when the selectivity index was $<1$, the product was more toxic against the macrophage cells than against the parasites [40].

Some previous studies on the leishmanicidal effect of larval products on Leishmania parasites in in vitro and in vivo models have reported potential therapeutic effects of larval ES of L. sericata on L. amazonensis [29] L. tropica [30], L. major [28] and L. panamensis [15]. Previous studies that evaluated in vitro models have concentrated on Leishmania sub-genus species [27, 28, 30].

In the present study, the in vitro leishmanicidal effect of the larval saliva and hemolymph of $L$. sericata against the promastigote and amastigote forms of $L$. tropica was demonstrated.

\section{Conclusion}

For the first time to our knowledge, the therapeutic effect of the larval saliva and hemolymph of $L$. sericata on the promastigote and amastigote forms of $L$. tropica has been demonstrated in this study. In addition, the toxic effect of these larval products on intact (peritoneal cells) and manipulated (J774A.1 cell line) macrophage cells was investigated.

It is worth mentioning that the larval hemolymph of $L$. sericata had equivalent effectiveness at $450 \mu \mathrm{g} / \mathrm{ml}$ compared with a standard drug $(100 \mu \mathrm{g} / \mathrm{ml})$, and its effect was maintained when the concentration was increased. The larval hemolymph has a strong toxic effect on $L$. tropica at completely safe concentrations for macrophage cells. Accordingly, larval products of $L$. sericata may be exploited as potential candidates for the treatment of cutaneous leishmaniasis. However, further studies are required to understand the components of the larval products and the mechanisms of inhibitory activities on leishmania parasites.

\footnotetext{
Abbreviations

CL: Cutaneous leishmaniasis; ACL: Anthroponotic cutaneous leishmaniasis; AmB: Amphotericin B; ES: Excretion and secretion; AMPs: Anti-microbial peptides; SGLs: Salivary gland lysates; SPH-TUMS: School of Public Health, Tehran University of Medical Sciences; IPA: Isopropyl alcohol; SDS-PAGE: Sodium dodecyl sulfate-polyacrylamide gel electrophoresis; PBS: Phosphate buffered saline; BCA: Bicinchoninic acid; BSA: Bovine serum albumin; CRTSDL: Center for Research and Training in Skin Diseases and Leprosy; NNN: Novy-MacnealNicolle; FBS: Fetal bovine serum; RPMI: Roswell Park Memorial Institute; DMEM: Dulbecco's Modified Eagle Medium; IP: Intraperitoneally; MTT: 3-(4.5-Dimethylthiazol-2-yl)-2,5-diphenyltetrazolium bromide; DMSO: Dimethyl sulfoxide; OD: Optical density; CC50: Cell cytotoxicity for 50\% of cells; IC50: Inhibitory concentration for $50 \%$ of parasite; SI: Selectivity index; \%l: Infection percentage; $\% D I$ : Decreased infection percentage; \%V: Viability of amastigote percentage; $\% D V$ : Decreased viability of amastigote percentage; GEE: Generalized estimating equation; SVI: Survival index; PL: Parasite load.
} 


\section{Acknowledgements}

The authors thank Dr. Latifi, Dr. Nategh and Dr. Mohammadi for their helpful and valuable comments and the staff of CRTSDL for their collaboration during the study. We would like to thank Dr. Shoja and Ms. Sheikh for their assistance. We are grateful to Ms. Azizi and Mr. Ghafari, TUMS-SPH, for their assistance in fly rearing.

\section{Authors' contributions}

$\mathrm{SR}, \mathrm{AKH}, \mathrm{AAA}, \mathrm{JR}, \mathrm{RA}, \mathrm{MB}, \mathrm{AV}$ and $\mathrm{KA}$ contributed to the design and implementation of the research, analysis of the results and writing of the manuscript. All authors read and approved the final manuscript.

\section{Funding}

This work was a part of PhD thesis that was funded and supported by the School of Public Health, Tehran University of Medical sciences (TUMS) (project no. 96-10-23/1396.4207) and the Center for Research and Training in Skin Diseases and Leprosy (CRTSDL).

\section{Availability of data and materials}

The dataset analyzed during the current study is available from the corresponding author on reasonable request.

\section{Ethics approval and consent to participate}

The Ethics committee of Tehran University of Medical Sciences approved all protocols describe in THE current study (IR.TUMS. 1396.4207).

\section{Consent for publication}

All authors Gave full consent to publish the article.

\section{Competing interests}

The authors have stated explicitly that there are no conflicts of interest in connection with this article.

\section{Author details}

1 Department of Medical Entomology and Vector Control, School of Public Health, Tehran University of Medical Sciences, Tehran, Iran. ${ }^{2}$ Center for Research and Training in Skin Diseases and Leprosy, Tehran University of Medical Sciences, Tehran, Iran. ${ }^{3}$ Pharmaceutical Chemistry, Department of Human Ecology, School of Public Health, Tehran University of Medical Sciences, Tehran, Iran. ${ }^{4}$ Department of Community Medicine and Epidemiology, School of Medicine Non-communicable Diseases Research Center Alborz, University of Medical Sciences, Karaj, Iran. ${ }^{5}$ Zoonoses Research Center, Research Institute for Health Development, Kurdistan University of Medical sciences, Sanandaj, Iran.

\section{Received: 27 June 2020 Accepted: 11 December 2020}

Published online: 11 January 2021

\section{References}

1. Control of the leishmaniases: report of a meeting of the WHO Expert Commitee on the Control of Leishmaniases. Geneva: WHO technical report series, no: 949; 2010;1-186.

2. de la Santé M. Leishmaniasis in high-burden countries: an epidemiological update based on data reported in 2014. Wkly Epidemiol Rec. 2016;91(22):286-96

3. WHO. Leishmaniasis: key fact. 2020. Retrieved June 17, 2020 from: https:// www.who.int/news-room/fact-sheets/detail/leishmaniasis.

4. WHO: Department of control of neglected tropical diseases. Working to overcome the global impact of neglected tropical diseases: first WHO report on neglected tropical diseases. Geneva: World Health Organization, 20109241564091 Contract No.: WHO/HTM/NTD/2010.1.

5. McGwire B, Satoskar A. Leishmaniasis: clinical syndromes and treatment. QJM. 2014;107(1):7-14.

6. Alvar J, Vélez ID, Bern C, Herrero M, Desjeux P, Cano J, et al. Leishmaniasis worldwide and global estimates of its incidence. PLOS ONE. 2012;7(5):e35671.

7. Akhavan A. Immune response of great gerbil against Phlebotomus papatasi saliva. Saarbrücken, Germany: LAP LAMBERT Academic Publishing; 2011.
8. Khamesipour A. Therapeutic vaccines for leishmaniasis. Expert Opin Biol Ther. 2014;14(11):1641-9.

9. Yaghoobi-Ershadi MR. Control of phlebotomine sand flies in Iran: a review article. J Arthropod Borne Dis. 2016;10(4):429.

10. Yaghoobi-Ershadi M. Reservoir host of cutaneous leishmaniasis in Iran. Tehran, Iran: Academic Press Center; 2008. p. 177-90.

11. Knöpfel N, Noguera-Morel L, Azorin D, Sanz F, Torrelo A, Hernández-Martín A. Cutaneous Leishmania tropica in children: report of three imported cases successfully treated with liposomal amphotericin B. J Eur Acad Dermatol Venereo. 2018;32(1):8-10.

12. Tahghighi A, Razmi S, Mahdavi M, Foroumadi P, Ardestani SK, Emami S, et al. Synthesis and anti-leishmanial activity of 5-(5-nitrofuran-2-yl)-1, 3, 4-thiadiazol-2-amines containing N-[(1-benzyl-1H-1, 2, 3-triazol-4-yl) methyl] moieties. Eur J Med Chem. 2012;50:124-8.

13. Cherniack EP. Bugs as drugs, Part 1: insects: the "new" alternative medicine for the 21st century. Altern Med Rev. 2010;15(2):124-35.

14. Ratcliffe NA, Mello CB, Garcia ES, Butt TM, Azambuja P. Insect natural products and processes: new treatments for human disease. Insect Biochem Mol Biol. 2011;41(10):747-69.

15. Cruz-Saavedra L, Díaz-Roa A, Gaona MA, Cruz ML, Ayala M, CortésVecino JA, et al. The effect of Lucilia sericata-and Sarconesiopsis magellanica-derived larval therapy on Leishmania panamensis. Acta Trop. 2016;164:280-9.

16. Valachova I, Prochazka E, Bohova J, Novak P, Takac P, Majtan J. Antibacterial properties of lucifensin in Lucilia sericata maggots after septic injury. Asian Pac J Trop Biomed. 2014;4(5):358-61.

17. Sherman RA, Mumcuoglu KY, Grassberger M, Tantawi TI. Maggot therapy. Biotherapy-history, principles and practice. Switzerland: Springer; 2013. p. 5-29.

18. Chambers L, Woodrow S, Brown A, Harris P, Phillips D, Hall M, et al. Degradation of extracellular matrix components by defined proteinases from the greenbottle larva Lucilia sericata used for the clinical debridement of non-healing wounds. Br J Dermatol. 2003;148(1):14-23.

19. Nigam Y, Bexfield A, Thomas S, Ratcliffe NA. Maggot therapy: the science and implication for CAM part II-maggots combat infection. Evid Based Complem Altern Med. 2006;3(3):303-8.

20. Kruglikova A, Chernysh S. Antimicrobial compounds from the excretions of surgical maggots, Lucilia sericata (Meigen) (Diptera, Calliphoridae). Entomol Rev. 2011;91(7):813-9.

21. Harris LG, Nigam Y, Sawyer J, Mack D, Pritchard DI. Lucilia sericata chymotrypsin disrupts protein adhesin-mediated staphylococcal biofilm formation. Appl Environ Microbiol. 2013;79(4):1393-5.

22. Pöppel A-K, Vogel H, Wiesner J, Vilcinskas A. Antimicrobial peptides expressed in medicinal maggots of the blow fly Lucilia sericata show combinatorial activity against bacteria. Antimicrob Agents Chemother. 2015:59(5):2508-14

23. Hassan MI, Amer MS, Hammad KM, Zidan MM. Antimicrobial activity for excretion and secretion of the Greenbottle Fly Larvae Lucilia Sericata (Meigen) (Diptera: Calliphoridae). J Egypt Soc Parasitol. 2016;240(3298):1-6

24. Malekian A, Djavid GE, Akbarzadeh K, Soltandallal M, Rassi Y, Rafinejad J, et al. Efficacy of maggot therapy on Staphylococcus aureus and Pseudomonas aeruginosa in diabetic foot ulcers: a randomized controlled trial. J Wound Ostomy Continence Nurs. 2019;46(1):25-9.

25. Alnaimat SM, Wainwright M, Aladaileh $\mathrm{SH}$. An initial in vitro investigation into the potential therapeutic use of Lucilia sericata maggot to control superficial fungal infections. Jordan J Biol Sci. 2013;147(624):1-6.

26. Pöppel A-K, Koch A, Kogel K-H, Vogel H, Kollewe C, Wiesner J, et al. Lucimycin, an antifungal peptide from the therapeutic maggot of the common green bottle fly Lucilia sericata. Biol Chem. 2014;395(6):649-56.

27. Laverde-Paz MJ, Echeverry MC, Patarroyo MA, Bello FJ. Evaluating the anti-leishmania activity of Lucilia sericata and Sarconesiopsis magellanica blowfly larval excretions/secretions in an in vitro model. Acta Trop. 2018;177:44-50.

28. Sanei-Dehkordi A, Khamesipour A, Akbarzadeh K, Akhavan AA, Mohammadi AMA, Mohammadi Y, et al. Anti Leishmania activity of Lucilia sericata and Calliphora vicina maggots in laboratory models. Exp Parasitol. 2016:170:59-65.

29. Arrivillaga J, Rodríguez J, Oviedo M. Preliminary evaluation of maggot (Diptera: Calliphoridae) therapy as a potential treatment for leishmaniasis ulcers. Biomedica. 2008:28(2):305-10. 
30. Polat E, Cakan H, Aslan M, Sirekbasan S, Kutlubay Z, Ipek T, et al. Detection of anti-leishmanial effect of the Lucilia sericata larval secretions in vitro and in vivo on Leishmania tropica: first work. Exp Parasitol. 2012;132(2):129-34

31. Crosskey R, Lane R, et al. House-flies, blow-flies and their allies (calyptrate Diptera). In: Richard P, et al., editors. Medical insects and arachnids. Springer: Berlin; 1993. p. 403-28.

32. Lysyk T. Effects of temperature, food, and sucrose feeding on longevity of the house fly (Diptera: Muscidae). Environ Entomol. 1991;20(4):1176-80.

33. Wolff $\mathrm{H}$, Hansson $\mathrm{C}$. Rearing larvae of Lucilia sericata for chronic ulcer treatment-an improved method. Acta Derm Venereol. 2005;85(2):126-31.

34. Rohousova I, Ozensoy S, Ozbel Y, Volf P. Detection of species-specific antibody response of humans and mice bitten by sand flies. Parasitology. 2005;130(5):493-9.

35. Heukeshoven J, Dernick R. Simplified method for silver staining of proteins in polyacrylamide gels and the mechanism of silver staining. Electrophoresis. 1985;6(3):103-12.

36. Tempone AG, Pimenta DC, Lebrun I, Sartorelli P, Taniwaki NN, de Andrade Jr HF, et al. Antileishmanial and antitrypanosomal activity of bufadienolides isolated from the toad Rhinella jimi parotoid macrogland secretion. Toxicon. 2008;52(1):13-21.

37. García M, Monzote L, Scull R, Herrera P. Activity of Cuban plants extracts against Leishmania amazonensis. ISRN Pharmacol. 2012;2012:1-7.

38. de Mello TF, Bitencourt HR, Pedroso RB, Aristides SM, Lonardoni MV, Silveira TG. Leishmanicidal activity of synthetic chalcones in Leishmania (Viannia) braziliensis. Exp Parasitol. 2014;136:27-34.

39. Huberman L, Gollop N, Mumcuoglu K, Block C, Galun R. Antibacterial properties of whole body extracts and haemolymph of Lucilia sericata maggots. J Wound Care. 2007;16(3):123-7.

40. Tempone AG, de Oliveira CM, Berlinck RG. Current approaches to discover marine antileishmanial natural products. Planta Med. 2011;77(06):572-85.

\section{Publisher's Note}

Springer Nature remains neutral with regard to jurisdictional claims in published maps and institutional affiliations.
Ready to submit your research? Choose BMC and benefit from:

- fast, convenient online submission

- thorough peer review by experienced researchers in your field

- rapid publication on acceptance

- support for research data, including large and complex data types

- gold Open Access which fosters wider collaboration and increased citations

- maximum visibility for your research: over $100 \mathrm{M}$ website views per year

At BMC, research is always in progress.

Learn more biomedcentral.com/submissions 